\title{
Genetic diversity studies in tomato (Solanum lycopersicum L.)
}

\author{
B. Rajasekhar Reddy ${ }^{1}$, Mula Pratapa Reddy ${ }^{2}$, Hameedunnisa Begum ${ }^{3}$ and \\ N. Sunil ${ }^{4}$ \\ ${ }^{I} P G$ Student, College of Horticulture, Dr. Y. S. R. Horticultural University, Hyderabad \\ ${ }^{2}$ Ph.D Scholar, Banaras Hindu University, I.Ag.Sci., Varanasi 221005, INDIA \\ ${ }^{3}$ Principal Scientist, Vegetable Research Station, DrYSRHU, Hyderabad-30, INDIA \\ ${ }^{4}$ Scientist, NBPGR Regional Station, Rajendra Nagar, Hyderabad-500030, AP, INDIA
}

\begin{abstract}
A study was conducted using nineteen exotic collections of tomato. Genetic divergence analysis following Mahalanobis $D^{2}$ statistics revealed considerable genetic diversity among 19 genotypes of tomato (Solanum lycopersicum L.) for all the eighteen quantitative characters which was pertaining to the growth, earliness, yield and quality. Fruit weight, plant height and number of fruits per plant contributed $92.40 \%$ to the total divergence. Appreciable diversity within and between the clusters was observed. The characters fruit weight, number of fruits per plant and plant height were the potent factors in differentiating the germplasm of tomato under study. Five clusters were fanned from the $D^{2}$ analysis using Tocher's method. Cluster II topped with maximum number of genotypes among cluster fanned, while maximum inter-cluster distance was observed between cluster III and IV followed by cluster IV and V.
\end{abstract}

Keywords: Solanum lycopersicum L., clusters, $D^{2}$ analysis, Solanaceae, germplasm, diversity

\section{Introduction}

Tomato ( $2 \mathrm{n}=24$ ) belonging to the family Solanaceae is an important vegetable crop of the world, which ranks next to potato in importance. Systematic study and evaluation of germplasm is of great importance for current and future agronomic and genetic improvement of the crop. Furthermore, if an improvement program is to be carried out, evaluation of germplasm is imperative, in order to understand the genetic background and breeding value of the available germplasm (Singh et al., 2002). Landraces are often heterogeneous and composed of different genotypes which are mostly homozygous and usually exhibit considerable genetic variation for quantitative and qualitative characteristics (Frankel et al., 1995).

Tomato crop has wider adaptability, high yielding potential and multipurpose uses in fresh as well as processed food industries. An improvement in yield and quality in self pollinated crops like tomato is normally achieved by selecting the genotypes with desirable character combinations existing in nature or by hybridization. Hence, present study was undertaken to assess the extent of genetic diversity in tomato.

\section{Materials And Methods}

Nineteen genotypes of tomato consisting of sixteen exotic collections and three varieties were evaluated in an augmented block design at National Bureau of Plant Genetic Resources (NBPGR) Regional Station, Hyderabad. The experiment laid out in eight blocks. In each block two genotypes of exotic collection and three varieties i.e., ArkaVikas, Marutham and Punjab Chhauhara which are used as checks are planted at a spacing of $60 \times 50 \mathrm{~cm}$ in a single row. Due to limited germplasm of each genotype the experiment is laid out of augmented block design. Observations recorded for eighteen characters viz., Plant height $(\mathrm{cm})$, number of primary branches, days to $50 \%$ flowering, number of clusters per plant, number of flowers per clusters, days to first fruit set, days to first fruit harvest, days to last fruit harvest, number of fruits per clusters, number of fruits per plant, fruit length $(\mathrm{cm})$, fruit width $(\mathrm{cm})$, fruit weight, fruit yield per plant $(\mathrm{kg})$, ascorbic acid $(\mathrm{mg} / 100 \mathrm{~g})$, acidity (\%), TSS ( ${ }^{\circ}$ Brix) and shelf life (days). Mahalanobis (1936) generalized distance $\left(\mathrm{D}^{2}\right)$ was used to determine the degree of divergence and the genotype were grouped into clusters following Tocher's method (Rao, 1952).

\section{Results And Discussion}

Mahalanobis $\mathrm{D}^{2}$ statistics helped in grouping of 19 genotypes of tomato into five clusters (Table I). Cluster I had three genotypes, cluster II had seven genotypes, cluster III had four genotypes, cluster IV had four genotypes and cluster $\mathrm{V}$ is solitary consisting of only one genotype. The inter and intra cluster distances (Table II) indicated that maximum inter cluster distance of 5689.99 was observed between the cluster III and IV followed by 5139.32 between cluster IV and V while the minimum cluster distance of 1917.70 was observed between clusters I and V followed by 2796.65 between cluster II and V. The maximum intra cluster distance of 
2661.48 was observed in cluster IV followed by 2010.36 in cluster III, while the minimum intra-cluster distance of zero was observed in the cluster $\mathrm{V}$ as it is solitary.

The percent contribution of eighteen characters for genetic divergence (Table III) showed that fruit weight contributed maximum (39.77\%) towards genetic divergence followed by plant height $(30.99 \%)$ and number of fruits per plant (21.64\%). Mohanty and Prusti (2001) also observed such maximum contribution of fruit weight and number of fruits per plant to total divergence of tomato germplasm. De et al. (1988) opined that traits contributing maximum towards the $\mathrm{D}^{2}$ values needed to be given more emphasis for deciding the clusters to be taken for the purpose of choice of parents for hybridization.

The results of Mahalanobis $\mathrm{D}^{2}$ statistics revealed substantial and desirable genetic diversity among 19 germplasm lines included in the present study for all the eighteen characters under consideration collectively.

Several authors also reported profound diversity in the germplasm of tomato by assessing genetic divergence on the basis of quantitative traits following Mahalanobis $\mathrm{D}^{2}$ statistics (Basavaraj et al., 2010 and Evgenidis et al., 2011). Average inter and intracluster distances revealed that, in general, intercluster distances were much higher than those of intracluster distances, suggesting homogeneous and heterogeneous nature of the germplasm lines within and between the clusters, respectively. These results are in accordance with the findings of Mahesha et al. (2006), Sekhar et al. (2008) in tomato.

The cluster mean analysis (Table IV) results had been interpreted for all the eighteen characters. In case of plant height, cluster IV had maximum plant height (131.33) followed by cluster II (92.74). In case of cluster mean values for number of primary branches per plant cluster IV had the highest number (22.56) followed by cluster III (16.19). Days to 50\% flowering was minimum (38.33 days) in cluster V followed by cluster II (38.71 days). In case of number of clusters per plant cluster $\mathrm{V}$ had maximum clusters per plant (27.32) followed by cluster II (18.26).

For number of per cluster, cluster IV had maximum value (6.97) followed cluster II (6.34). Days to first fruit set was maximum in cluster V (40.92 days) followed by cluster II (43.63 days). Minimum days to first fruit harvest was observed in cluster II (82.69 days) followed by cluster V (82.83). In case of days to last fruit harvest, cluster I had maximum value (139.89 days) followed by cluster II (134.24 days), maximum number of fruits per cluster were observed in IV (40.20) followed by cluster II (4.60). In case of number of fruits per plant cluster III had the maximum value (66.23) followed by cluster II (50.90). Fruit length was maximum in cluster V $(5.94 \mathrm{~cm})$ followed by cluster III $(5.61 \mathrm{~cm})$. Fruit width was maximum in cluster III $(3.99 \mathrm{~cm})$ followed by cluster IV $(3.68 \mathrm{~cm})$. Maximum fruit weight was observed in cluster III $(83.25 \mathrm{gm})$ followed by cluster I $(77.67 \mathrm{~g})$. In case of fruit yield per plant, cluster $\mathrm{V}$ had maximum value $\left(2.09 \mathrm{~kg} \mathrm{plant}^{-1}\right)$ followed by cluster III $(1.51 \mathrm{~kg} / \mathrm{plant})$. For ascorbic acid, cluster $\mathrm{V}$ recorded maximum value $(34.47 \mathrm{mg} / 100 \mathrm{~g})$ followed by cluster IV (26.42mg.g). Acidity was maximum in cluster IV $(0.44 \%)$ followed by cluster I $(0.38 \%)$. Total soluble solids (TSS) was maximum in cluster IV $\left(6.75^{\circ} \mathrm{Brix}\right)$ followed by cluster II $\left(5.97{ }^{\circ} \mathrm{Brix}\right)$. In case of self life, cluster I had the maximum shelf life (31.17 days) followed by cluster III (27.42 days)

\section{Conclusion}

To improve for earliness, hybridization between cluster V and II is better in which genotypes with earliness are included. For fruit weight hybridization between cluster III and I would be better in which genotypes with more fruit weight were included. To improve number of fruits per plant, hybridization between cluster III and Cluster II would be better in which genotypes with more number of fruits per plant were included.

\begin{tabular}{lcc}
\hline Source & Times Ranked 1st & Contribution \% \\
\hline 1 Plant Height cm & 53 & 30.99 \\
2 Primary Branches & 0 & 0.00 \\
3 Days to 50\% Flowering & 0 & 0.00 \\
4 Clusters/ Plant & 2 & 1.17 \\
5 Flowers/ Cluster & 0 & 0.00 \\
6 1st Fruit Set & 0 & 0.00 \\
7 1st Fruit Harvest & 4 & 2.34 \\
8 Last Fruit Harvest & 2 & 1.17 \\
9 Fruits/ Cluster & 0 & 0.00 \\
10 Fruits/ Plant & 37 & 21.64 \\
11 Fruit Length (cm) & 0 & 0.00 \\
12 Fruit Width (cm) & 0 & 0.00 \\
13 Fruit Weight (gm) & 68 & 39.77 \\
14 Fruit Yield (kg/ Plant) & 0 & 0.00 \\
15 Asccorbic Acid & 2 & 1.17 \\
16 Acidity & 0 & 0.00 \\
17 TSS & 0 & 0.00 \\
18 Shelf Life & 3 & 1.75 \\
\hline Table I. Percent contribution of quantitative traits towards divergence in 19 genotypes of \\
$\quad$ tomato & &
\end{tabular}


Table II. Average intra (bold) and inter cluster $\mathrm{D}^{2}$ values for five clusters in 19 genotypes of tomato (Tocher's method)

\begin{tabular}{lrrrrr}
\hline & 1 Cluster & 2 Cluster & 3 Cluster & 4 Cluster & 5 Cluster \\
\hline ICluster & $\mathbf{8 6 7 . 1 9}$ & 3769.29 & 3034.80 & 4598.59 & 1917.70 \\
II Cluster & & $\mathbf{1 7 1 6 . 7 8}$ & 4044.14 & 4624.96 & 2796.35 \\
III Cluster & & $\mathbf{2 0 1 0 . 3 6}$ & 5689.90 & 3059.19 \\
IV Cluster & & & $\mathbf{2 6 6 1 . 4 8}$ & 5139.32 \\
V Cluster & & & & $\mathbf{0 . 0 0 0}$ \\
\hline
\end{tabular}

Table III. Grouping of germplasm into clusters

\begin{tabular}{lll}
\hline Cluster & Number of gemless & Genotypes \\
\hline I cluster & 3 & EC671592, EC671599, EC676816 \\
II cluster & 7 & $\begin{array}{l}\text { EC677058, EC671593, EC677079, } \\
\text { EC677051, Marutham, Punjab Chhauhara, Arka } \\
\text { Vikas }\end{array}$ \\
& & EC677040, EC677206, EC671598, EC677063 \\
III cluster & 4 & EC676793, EC677203, EC677202, EC677204 \\
IVcluster & 4 & EC676790 \\
V cluster & 1 &
\end{tabular}

Table IV. Mean values of clusters for eighteen quantitative traits in 19 genotypes

\begin{tabular}{|c|c|c|c|c|c|c|c|c|c|}
\hline $\begin{array}{c}\text { Cluster } \\
\text { No }\end{array}$ & $\begin{array}{c}\text { Plant } \\
\text { Height } \mathrm{cm} \\
\end{array}$ & $\begin{array}{c}\text { Primary } \\
\text { Branches }\end{array}$ & $\begin{array}{l}\text { to } 50 \% \\
\text { vering }\end{array}$ & $\begin{array}{c}\text { Clusters/ } \\
\text { Plant }\end{array}$ & $\begin{array}{l}\text { Flowers/ } \\
\text { Cluster }\end{array}$ & $\begin{array}{c}\text { 1st Fruit } \\
\text { Set }\end{array}$ & $\begin{array}{l}\text { 1st Fruit } \\
\text { Harvest }\end{array}$ & $\begin{array}{c}\text { Last Fruit } \\
\text { Harvest }\end{array}$ & $\begin{array}{l}\text { Fruits/ } \\
\text { Cluster }\end{array}$ \\
\hline 1 & 78.181 & 12.701 & .111 & 5.743 & 5.713 & 47.25 & 92.944 & 139.889 & 3.662 \\
\hline II & 92.744 & 15.432 & .714 & 18.264 & 6.341 & 43.631 & 82.69 & 134.238 & 4.472 \\
\hline III & 84.542 & 16.188 & .417 & 11.646 & 5.829 & 51.5 & 96.833 & 131.583 & 4.604 \\
\hline IV & 131.333 & 22.563 & .417 & 6.846 & 6.971 & 44.917 & 92.167 & 130.583 & 4.896 \\
\hline $\mathrm{V}$ & 74.625 & 13.813 & .333 & 27.321 & 5.512 & 40.917 & 82.833 & 129 & 3.196 \\
\hline \multicolumn{10}{|c|}{ Table IV. Conti.... } \\
\hline Fruits Plant $^{-1}$ & $\begin{array}{c}\text { Fruit } \\
\text { Length } \\
(\mathrm{cm})\end{array}$ & $\begin{array}{c}\text { Fruit } \\
\text { Width }(\mathrm{cm})\end{array}$ & $\begin{array}{c}\text { Fruit } \\
\text { Weight (g) }\end{array}$ & $\begin{array}{c}\text { Fruit Yield/ } \\
\text { Plant }\end{array}$ & \multicolumn{2}{|c|}{ Ascorbic Acid } & Acidity & TSS & Shelf Life \\
\hline 24.410 & 4.860 & 3.669 & 77.667 & 0.554 & \multicolumn{2}{|c|}{23.044} & 0.379 & 5.699 & 31.167 \\
\hline 50.902 & 3.947 & 2.977 & 39.952 & 1.183 & \multicolumn{2}{|c|}{23.381} & 0.308 & 5.968 & 22.262 \\
\hline 66.229 & 5.613 & 3.992 & 83.250 & 1.513 & \multicolumn{2}{|c|}{22.567} & 0.296 & 5.421 & 27.417 \\
\hline 30.812 & 4.729 & 3.675 & 66.333 & 1.246 & \multicolumn{2}{|c|}{26.417} & 0.438 & 6.746 & 20.833 \\
\hline 35.854 & 5.938 & 3.458 & 72.000 & 2.088 & \multicolumn{2}{|c|}{34.467} & 0.313 & 4.921 & 7.167 \\
\hline
\end{tabular}

\section{Acknowledgements}

I am highly thankful to College of Horticulture, Dr Y. S. R. Horticultural University, Hyderabad and NBPGR Regional Station, Hyderabad for providing the facilities for conducting the research.

\section{References}

[1]. Basavaraj, N.S., Patil, B.C., Salimath, P.M., Hosamani, R.M. and Krishnaraj, P.U. 2010. Genetic divergence in tomato (Solanum lycoperiscon [Mill.] Wettsd.). Karnataka Journal of Agricultural Sciences, 23(3) : 508-539, 5 ref.

[2]. De, R. N., Seetharaman, R., Sinha, M.T. and Banerjee, S.P. 1988. Genetic divergence in rice. Indian Journal of Genetics and Plant Breeding, $48: 189-194$.

[3]. Evgenidis, G., Traka-Mavrona, E. and Koutsika - Sotiriou, M. 2011. Principal component and clusters analysis as a tool in the assessment of tomato hybrids and cultivars. International Journal of Agronomy, 27 ref.

[4]. Mahalanobis, P. C., 1936. On the generalized distance in statristics. Proceedings of National Academy of Sciences, (India.), 2: 4955 .

[5]. Mahesha, D.K., Apte, U.B. and Jadhav, B.B. 2006. Studies on genetic divergence in tomato (Lycopersicon esculentum Mill.). Crop Research, 32(3): 401-402.

[6]. Rao, C. R. 1952. Advanced Statistical Methods in Biometrical Research. John Wiley and Sons Inc., Newyork, PP-390.

[7]. Sekhar, L., Prakash, B.G., Salimath, P.M., Sridevi, O. and Patil, A.A. 2008. Genetic diversity among some productive hybrids of tomato (Lycopersicon esculentum Mill.). Karnataka Journal of Agricultural Science, 21(2): 264-265.

[8]. Singh, J. K., Singh, J. P., Jain, S. K., Aradhana, J. and Joshi, A. 2002. Studies on genetic variability and its importance in tomato (Lycopesicum esculentum Mill.). Progressive Horticulture, 34: 77-79.

[9]. Mohanty, B.K. and Prusti, A.M. 2001. Analysis of genetic distance in tomato. Research on Crops. 2(3): $382-385$

[10]. Frankel, H., Brudon, J. J. and Peacock, W. J. 1995. Landraces in transit-the threat perceived. Diversity. 11: 14-15. 